Article

\title{
Devolatilization Kinetics of Different Types of Bio-Coals Using Thermogravimetric Analysis
}

\author{
Asmaa A. El-Tawil ${ }^{1, *}$, Hesham M. Ahmed ${ }^{1,2}$, , Lena Sundqvist Ökvist ${ }^{1,3}$ and Bo Björkman ${ }^{1}$ \\ 1 MiMeR, Luleå University of Technology, 97187 Luleå, Sweden; Hesham.ahmed@ltu.se (H.M.A.); \\ lena.sundqvist-oqvist@ltu.se (L.S.Ö.); Bo.Bjorkman@ltu.se (B.B.) \\ 2 Central Metallurgical Research and Development Institute, P.O Box 87, Helwan, Cairo 11421, Egypt \\ 3 Swerim AB, 97125 Luleå, Sweden \\ * Correspondence: asmaa.el-tawil@1tu.se; Tel.: +46-920-493131
}

Received: 17 January 2019; Accepted: 29 January 2019; Published: 1 February 2019

\begin{abstract}
The interest of the steel industry in utilizing bio-coal (pre-treated biomass) as $\mathrm{CO}_{2}$-neutral carbon in iron-making is increasing due to the need to reduce fossil $\mathrm{CO}_{2}$ emission. In order to select a suitable bio-coal to be contained in agglomerates with iron oxide, the current study aims at investigating the thermal devolatilization of different bio-coals. A thermogravimetric analyzer (TGA) equipped with a quadrupole mass spectrometer (QMS) was used to monitor the weight loss and off-gases during non-isothermal tests with bio-coals having different contents of volatile matter. The samples were heated in an inert atmosphere to $1200{ }^{\circ} \mathrm{C}$ at three different heating rates: 5,10 , and $15{ }^{\circ} \mathrm{C} / \mathrm{min} . \mathrm{H}_{2}, \mathrm{CO}$, and hydrocarbons that may contribute to the reduction of iron oxide if contained in the self-reducing composite were detected by QMS. To explore the devolatilization behavior for different materials, the thermogravimetric data were evaluated by using the KissingerAkahira-Sonuse (KAS) iso-conversional model. The activation energy was determined as a function of the conversion degree. Bio-coals with both low and high volatile content could produce reducing gases that can contribute to the reduction of iron oxide in bio-agglomerates and hot metal quality in the sustained blast furnace process. However, bio-coals containing significant amounts of $\mathrm{CaO}$ and $\mathrm{K}_{2} \mathrm{O}$ enhanced the devolatilization and released the volatiles at lower temperature.
\end{abstract}

Keywords: devolatilization; torrefied biomass; bio-coal; volatile matter; iso-conversional method

\section{Introduction}

The blast furnace (BF) is the most widely used technology for producing hot metal for steelmaking. In the $\mathrm{BF}$, iron oxide is reduced to metallic iron by fossil carbon resources (coke, coal, oil, natural gas, etc.). The reducing conditions in the furnace are created by top-charged (coke) and tuyere-injected (pulverized coal, oil, etc.) reducing agents [1]. The total consumption of coke is about $300 \mathrm{~kg} / \mathrm{t}$ hot metal [1,2] depending on the amount of auxiliary reducing agents [3]. The steel industry aims to reduce coke consumption and minimize $\mathrm{CO}_{2}$ emissions by improving the energy efficiency of the process and by investigating the use of carbon-neutral materials such as bio-coal (pre-treated biomass) to substitute part of the fossil sources. $\mathrm{CO}_{2}$ emitted for every ton of steel produced was on average 1.83 tons in 2017. According to the World Steel Association, the iron and steel industry accounts for approximately 7-9\% of total world $\mathrm{CO}_{2}$ emission [4]. The European Union (EU) has set a target to cut $20 \%$ of the $\mathrm{CO}_{2}$ emissions, to achieve a $20 \%$ improvement in energy efficiency, and to increase the renewable energy by $20 \%$ by 2020 ; by 2050 the aim is to cut $80 \%$ of the $\mathrm{CO}_{2}$ emissions [5]. Several studies report the decrease in fossil $\mathrm{CO}_{2}$ emissions by using biomass [6,7]. Use of biomass resources is a possible alternative in Sweden, as forestland amounts to about 28.1 million hectares [8]. 
The use of raw biomass as a reducing agent in a BF is not possible because of the high moisture content, low content of fixed carbon $\left(\mathrm{C}_{\mathrm{fix}}\right)$, as well as high contents of volatile matter $(\mathrm{VM})$ and oxygen $[9,10]$. Different technologies can be applied to pre-treat biomass into products with properties suitable for the metallurgical industry. Pre-treatment methods like pyrolysis [11], torrefaction [12], etc., result in higher content of $\mathrm{C}_{\mathrm{fix}}$, lower VM and oxygen, and improved grindability, properties which, overall, correspond to a product whose quality resembles that of coal [12].

Top-charging of self-reducing composites constituted of iron ore and bio-coal into the BF is one way to introduce bio-coal and partially replace fossil carbon. Furthermore, this approach has the potential to lower the thermal reserve zone temperature of the BF as a result of the direct reduction of iron oxide in the agglomerates. The indirect reduction of $\mathrm{FeO}$ with $\mathrm{CO}$ at a lower temperature shifts towards the formation of more metallic iron at a specific partial pressure of $\mathrm{CO}$. This results in higher gas efficiency of the $\mathrm{BF}$, and the $\mathrm{CO}_{2}$ emission is decreased. However, to achieve the maximum positive effect, the VM present in bio-coals contained in the composites should contribute to the reduction and not be released and lost with the BF top gas.

One of the features of biomass is the presence of considerable amounts of metal oxides of potassium, calcium, and magnesium [13] in the ash. The ash content is often less than $1 \%$ in woody bio-mass but may vary up to $15 \%$ in some herbaceous biomass and forestry residues [13,14]. The effect of inorganics on the thermal degradation of biomass has been extensively studied [15-17]. In general, inorganics retained in char during pyrolysis act as catalysts for char forming and fragmentation reactions $[13,16,18]$.

There are several available methods for analyzing the kinetic data of devolatilization reactions [19]. These methods may be classified according to the experimental conditions selected and the mathematical analysis performed. Experimentally, either isothermal or non-isothermal methods are employed. The main mathematical approaches employed can be divided into model-fitting and iso-conversional methods [19]. The devolatilization of solid materials, such as biomass, is classified as a heterogeneous chemical reaction. The reaction kinetics of a heterogeneous reaction can be affected by, for example, the breakage and redistribution of chemical bonds, changing reaction geometry, and the interfacial diffusion of reactants and products [20]. Iso-conversional methods are considered an appropriate means of estimating the apparent activation energy, $E_{a}$, of heterogeneous reactions.

There are numerous studies on biomass pyrolysis using thermal analysis [21-29]. The effects of important parameters such as particle size and heating rate have been studied by Mani et al. [26] and Biagini et al. [27]. The devolatilization kinetics of main components of raw biomass and its dependence on lignin, cellulose, and hemicellulose under different conditions (inert or oxidizing) [21-25] have been investigated using the iso-conversional method. Tharaka et al. [28] applied the iso-conversional model on the devolatilization of raw and torrefied eucalyptus at different heating rates $\left(5^{\circ} \mathrm{C} / \mathrm{min}\right.$ to $20^{\circ} \mathrm{C} / \mathrm{min}$ ) with temperatures ranging from 150 to $700{ }^{\circ} \mathrm{C}$. The kinetic analysis showed that torrefied eucalyptus has higher $\mathrm{E}_{\mathrm{a}}$ values than raw eucalyptus. Tran et al. [29] studied the pyrolysis of torrefied stump materials using the Distributed Activation Energy Model (DAEM) as well as a model involving the three components lignin, cellulose, and hemicellulose. It was observed that the torrefied stump has a higher activation energy than the raw stump. Up to now, there is limited information in the literature about the relation between devolatilization kinetics of bio-coals and their properties for use in self-reducing bio-agglomerates.

The purpose of this work was to investigate the devolatilization behavior and the related kinetics of different types of bio-coals when used in self-reducing composites. In the BF, the temperature of the top-charged material will increase rather quickly during the descent in the upper part. Ideally, all the carbon and hydrogen contained in the top-charged bio-coal should contribute to the reduction. The characterization of the devolatilization of the bio-coal is thus important to understand the behavior of bio-coal included in iron ore composites charged into a BF. 


\section{Kinetic Theory}

The devolatilization of lignocellulosic biomass is complex, as several reactions occur simultaneously during its thermal decomposition. Predicting the exact reaction mechanism is difficult, but the kinetic parameters of biomass devolatilization can be calculated by assuming a simplified single-step reaction mechanism. This reaction can be described by the rate equation, as presented in Equation (1) [30]:

$$
\frac{d \alpha}{d t}=k(T) f(\alpha)
$$

The dependency of the rate constant on temperature can be expressed as:

$$
\mathrm{k}(\mathrm{T})=A e^{\left(-\frac{E_{\alpha}}{R T}\right)}
$$

By combining Equation (1) and Equation (2), Equation (3) will be:

$$
\frac{d \alpha}{d t}=A e^{\left(-E_{\alpha} / R T\right)} f(\alpha)
$$

where $\alpha, \mathrm{R}, A, E_{\alpha}$, and $f(\alpha)$ denote the extent of conversion, gas constant, pre-exponential factor, activation energy, and reaction function, respectively. The reaction model can be expressed by using different mathematical forms that are tabulated elsewhere [30] and known as model fitting.

The conversion degree $(\alpha)$ is defined as follows:

$$
\alpha=\frac{m_{i}-m_{a}}{m_{i}-m_{f}}
$$

where $m_{i}$ is the initial mass of the sample, $m_{a}$ is the actual mass at a specific time, and $m_{f}$ is the mass after finalized devolatilization.

For devolatilization experiments performed non-isothermally at a constant heating rate $\left(\beta_{I}\right)$, the temperature $(\mathrm{T})$ changes linearly with time $(\mathrm{t})$ as in Equation (5):

$$
\beta_{I}=\frac{d T}{d t}
$$

where the index $I$ denotes different heating rates.

For a constant heating rate, Equation (3) can be modified to Equation (6):

$$
\frac{d \alpha}{d T}=\frac{A}{\beta} e^{\left(-E_{\alpha} / R T\right)} f(\alpha)
$$

Equation (6) can be written in an integral form to give Equation (7):

$$
g(\alpha)=\int_{0}^{\alpha} \frac{d \alpha}{f(\alpha)}=\frac{A}{\beta} \int_{0}^{T} e^{(-E / R T)} d T
$$

where $g(\alpha)=\int_{0}^{\alpha}[f(\alpha)]^{-1} d \alpha$ is the integral form of the reaction model [30]. The drawbacks of model-fitting to determine a reliable kinetic triplet of $A, E$, and $f(\alpha)$ or $g(\alpha)$ can be resolved by using iso-conversional methods.

The iso-conversional principle states that the reaction rate $\left[\left(\frac{d \alpha}{d t}\right)_{\alpha, I}\right]$ at a specific extent of conversion is a function of temperature only, and $f(\alpha)$ does not depend on T [31]. Assuming that $f(\alpha)$ at a given conversion degree is independent of temperature, the kinetic parameters can be obtained from a set of runs from the relation between reaction rate versus temperature (differential method) or from that between weight loss versus temperature (integral method). The drawback of 
differential methods compared to integral methods is that the former are sensitive to inaccuracies in the experimentally determined reaction rate; therefore, integral methods are often preferred [32].

Among the integral methods, the Kissinger-Akahira-Sunose (KAS) iso-conversional model is common because of its relatively higher accuracy in estimated kinetic [33]. The KAS model is represented by a linear Equation (8) [22], in which the apparent $E_{\alpha}$ can be obtained by plotting $\ln \frac{\beta_{I}}{T_{\alpha I}^{2}}$ versus $\frac{1000}{T_{\alpha I}}$ for a given value of conversion, $\alpha$, where the slope is equal to $\frac{-E_{a}}{\mathrm{R}}$.

$$
\ln \frac{\beta_{I}}{T_{\alpha I}^{2}}=\ln \left(\frac{A_{\alpha} \mathrm{R}}{E_{\alpha g_{\alpha}}}\right)-\frac{E_{\alpha}}{\mathrm{RT}_{\alpha I}}
$$

\section{Materials and Methods}

\subsection{Materials and Characterization}

The seven different types of bio-coals selected for this study are presented in Table 1 . The bio-coals were pulverized and, by sieving, the fraction of $75-150 \mu \mathrm{m}$ to be used in TGA was obtained. After drying, the pulverized materials were stored in a desiccator. The proximate and ultimate analyses of each bio-coal analyzed by ALS Scandinavia AB using standard methods are given in Table 2. Bio-coals (TFR, TW, and TSD) prepared at low temperature had high content of VM \% and less $\mathrm{C}_{\text {fix }} \%$. The opposite was seen for bio-coals (HTT, PA, PB, and CC) prepared at high temperature.

Table 1. Selected bio-coals with preparation temperatures and times.

\begin{tabular}{|c|c|c|c|c|c|}
\hline $\begin{array}{l}\text { Bio-Coal } \\
\text { Type }\end{array}$ & Bio-Coal & Origin & $\begin{array}{c}\text { Temperature, } \\
{ }^{\circ} \mathrm{C}\end{array}$ & Time, min & Abbreviation \\
\hline \multirow{3}{*}{$\begin{array}{c}\text { Highly } \\
\text { volatile } \\
\text { bio-coals }\end{array}$} & $\begin{array}{l}\text { Torrefied forest } \\
\text { residue }\end{array}$ & $\begin{array}{l}\text { Top and branches } \\
\text { pine / spruce }\end{array}$ & 286 & 6 & TFR \\
\hline & Torrefied saw dust & Spruce & 297 & 6 & TSD \\
\hline & Torrefied willow & Willow & 330 & 6 & TW \\
\hline \multirow{4}{*}{$\begin{array}{c}\text { Lowly } \\
\text { volatile } \\
\text { bio-coals }\end{array}$} & $\begin{array}{l}\text { High-temperature } \\
\text { torrefied }\end{array}$ & $\begin{array}{c}50 \% \text { Pine } / 50 \% \\
\text { spruce }\end{array}$ & 350 & 8 & HTT \\
\hline & Pine A & Pine & 350 & 14 & PA \\
\hline & Pine B & Pine & 400 & 14 & PB \\
\hline & Charcoal & $\begin{array}{l}\text { Mixture of pine, } \\
\text { birch, alder, aspen }\end{array}$ & 550 & - & $\mathrm{CC}$ \\
\hline
\end{tabular}

Table 2. Proximate and ultimate values of the used bio-coals materials (dry basis).

\begin{tabular}{cccc|ccccc}
\hline \multirow{2}{*}{ Bio-Coals } & \multicolumn{3}{c|}{ Proximate Analysis (wt \%) } & \multicolumn{5}{c}{ Ultimate Analysis (wt \%) } \\
\cline { 2 - 9 } & $\mathbf{C}_{\text {fix }}$ & VM & Ash & C $_{\text {tot }}$ & H & N & S & O \\
\hline TFR & 23.6 & 73.2 & 3.2 & 52.0 & 5.9 & 0.57 & 0.035 & 35.2 \\
TSD & 24.0 & 75.6 & 0.45 & 57.1 & 5.9 & 0.12 & 0.004 & 36.4 \\
TW & 24.7 & 73.3 & 2.0 & 52.7 & 5.8 & 0.30 & 0.021 & 39.2 \\
HTT & 60.8 & 38.2 & 1.0 & 75.3 & 4.9 & 0.10 & 0.008 & 18.8 \\
PA & 70.3 & 28.7 & 1.0 & 78.6 & 4.4 & 0.23 & $<0.01$ & 15.8 \\
PB & 79.1 & 19.7 & 1.2 & 85.0 & 3.8 & 0.30 & $<0.01$ & 9.70 \\
CC & 80.7 & 18.6 & 0.70 & 87.0 & 3.4 & 0.25 & $<0.004$ & 8.30 \\
\hline
\end{tabular}

$\mathrm{C}_{\text {Fix }}$ : Fixed carbon; VM: volatile matter; $\mathrm{C}_{\text {tot }}$ : Total carbon; H: hydrogen; N: nitrogen; S: sulphur; O: oxygen.

The contents of metal oxides in bio-coals are presented in Table 3. Higher content of the metal oxides $\mathrm{K}_{2} \mathrm{O}, \mathrm{CaO}$, and $\mathrm{MgO}$ were present in TFR and TW than in TSD. 
Table 3. Metal oxides in bio-coals (Wt \%, dry basis).

\begin{tabular}{lcccccccccc}
\hline Bio-coals & $\mathrm{Al}_{\mathbf{2}} \mathbf{O}_{3}$ & $\mathbf{C a O}$ & $\mathbf{S i O}_{2}$ & $\mathrm{Fe}_{\mathbf{2}} \mathbf{O}_{\mathbf{3}}$ & $\mathbf{K}_{\mathbf{2}} \mathbf{O}$ & $\mathbf{M g O}$ & $\mathbf{M n O}$ & $\mathbf{N a}_{\mathbf{2}} \mathbf{O}$ & $\mathbf{P}_{\mathbf{2}} \mathbf{O}_{5}$ & $\mathbf{T i O}_{2}$ \\
\hline TFR & 0.047 & 0.872 & 0.618 & 0.044 & 0.238 & 0.124 & 0.062 & 0.014 & 0.151 & 0.004 \\
TSD & 0.003 & 0.122 & 0.033 & 0.011 & 0.051 & 0.046 & 0.013 & 0.003 & 0.008 & 0.000 \\
TW & 0.004 & 0.494 & 0.019 & 0.003 & 0.230 & 0.076 & 0.004 & 0.005 & 0.142 & 0.000 \\
HTT & 0.024 & 0.310 & 0.305 & 0.079 & 0.145 & 0.061 & 0.040 & 0.023 & 0.032 & 0.001 \\
PA & 0.032 & 0.270 & 0.235 & 0.007 & 0.148 & 0.074 & 0.035 & 0.010 & 0.021 & 0.001 \\
PB & 0.013 & 0.339 & 0.067 & 0.006 & 0.167 & 0.096 & 0.043 & 0.004 & 0.024 & 0.000 \\
CC & 0.006 & 0.317 & 0.028 & 0.009 & $<0.002$ & 0.112 & 0.044 & $<0.009$ & 0.006 & 0.001 \\
\hline
\end{tabular}

\subsection{Experimental Method}

The experiments were performed using a TGA, Netzsch STA 409 instrument (sensitivity $\pm 1 \mu \mathrm{g}$ ) (Netzsch, Selb, Germany) attached to a Quadrupole Mass Spectroscopy (QMS, Netzsch, Selb, Germany) to monitor the mass loss and off-gases, respectively. The TGA used in this study is described in detail in reference [34]. In the mass spectrometer, compounds are ionized and separated on the basis of the mass/charge $(\mathrm{m} / \mathrm{z}$ ) ratio number. During the devolatilization experiments, $50-53 \mathrm{mg}$ of sample was placed in an alumina crucible and heated from room temperature up to $1200^{\circ} \mathrm{C}$ at the pre-specified heating rates of 5,10 , and $15{ }^{\circ} \mathrm{C} / \mathrm{min}$ under argon gas $(99.999 \%)$, with a flow rate of $200 \mathrm{~mL} / \mathrm{min}$. The samples were then cooled down at a rate of $20^{\circ} \mathrm{C} / \mathrm{min}$. To eliminate errors from the buoyancy effect, correction measurements were carried out. Repeated devolatilization tests in the TGA showed consistent results without any significant variation.

\section{Results and Discussion}

\subsection{Thermogravimetric Analysis}

Figure 1 shows the TG curves for bio-coals at the heating rate of $5^{\circ} \mathrm{C} / \mathrm{min}$. As seen from the plots, the weight loss for TFR, TW, and TSD began at $\sim 200^{\circ} \mathrm{C}$ and proceeded rapidly up to $800^{\circ} \mathrm{C}$, while the weight loss of HTT and PA started at $\sim 300^{\circ} \mathrm{C}$, and that of PB and CC started at $\sim 450{ }^{\circ} \mathrm{C}$. As expected, the pre-treatment temperature affected the starting temperature of devolatilization.

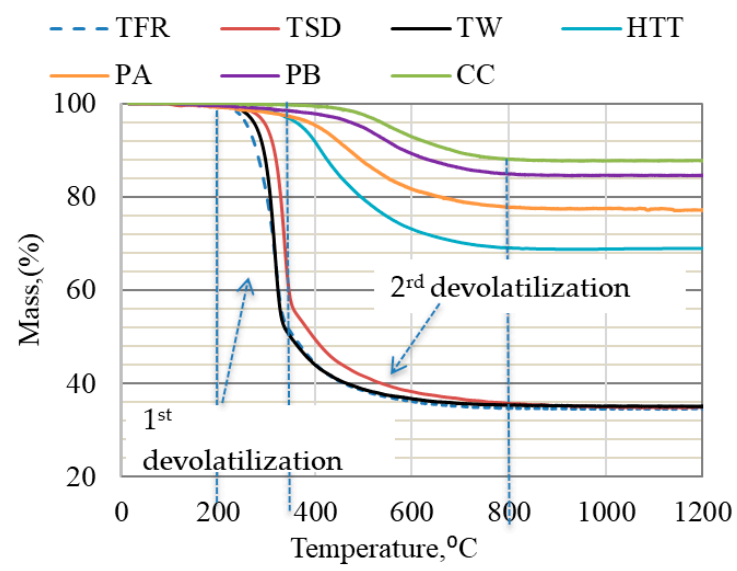

Figure 1. TGA of bio-coals conducted in Ar gas at a heating rate of $5{ }^{\circ} \mathrm{C} / \mathrm{min}$ up to $1200{ }^{\circ} \mathrm{C}$.

The devolatilization of bio-coal is linked to the presence of three main biomass components: hemicellulose, cellulose, and lignin [35]. The main DTG (derivative thermogravimetry) peak is, according to Marion et al. [36], attributed to cellulose decomposition, accompanied by a shoulder at the lower temperature, which is related to hemicellulose decomposition, and a flat tail at high temperature corresponding to lignin decomposition. The DTG curves deduced for TFR, TW, and TSD indicated two devolatilization steps, as can be seen in Figure 2. The first step of devolatilization started at $\sim 20{ }^{\circ} \mathrm{C}$ and continued until $350{ }^{\circ} \mathrm{C}$, and the second step started at $350{ }^{\circ} \mathrm{C}$ and continued until $800{ }^{\circ} \mathrm{C}$. These 
two steps of devolatilization are in agreement with findings by other researchers [35,37]. On the basis of findings by Marion et al. [36], the higher peak in the first devolatilization step for TFR, TW, and TSD can be likely attributed to the presence of cellulose residues. On the other hand, the devolatilization of HTT, PA, and PB occurred in one step, starting from $300^{\circ} \mathrm{C}$ and continuing until $800^{\circ} \mathrm{C}$. Similarly, CC only had one step of devolatilization, which started at $\sim 450{ }^{\circ} \mathrm{C}$. The main peak and flat tailing section for HTT, PA, PB, and CC shifted to a higher temperature, compared to highly volatile bio-coals. This was likely due to the decomposition of lignin which, according to the literature, occurs slowly over a broad temperature range $\left(160-900{ }^{\circ} \mathrm{C}\right)$ [35].

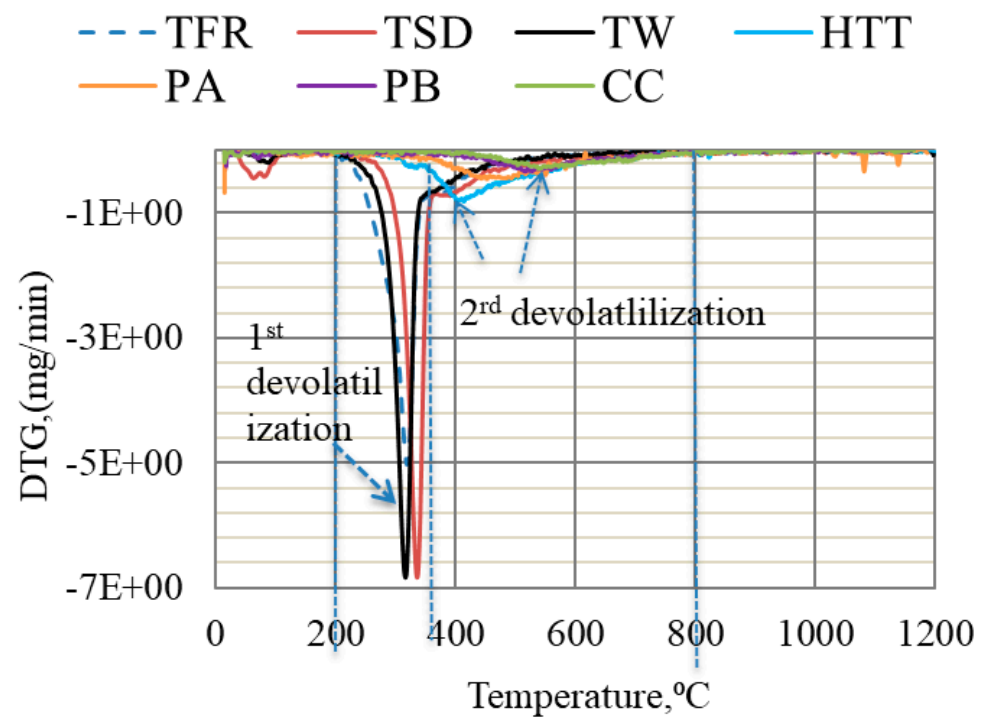

Figure 2. DTG of bio-coals conducted in Ar gas at a heating rate of $5^{\circ} \mathrm{C} / \mathrm{min}$ up to $1200^{\circ} \mathrm{C}$.

\subsection{Off-Gas Analysis during the Thermal Decomposition of Bio-Coals}

The thermal decomposition of bio-coals is caused by breaks of chemical bonds and release of VM as temperature increases. When and how this occurs influences the possible contribution of volatiles to reduction. It is important to note at which temperature interval different bio-coals will release the volatile matter. Gases $\left(\mathrm{CO}, \mathrm{CO}_{2}\right.$, and $\left.\mathrm{H}_{2}\right)$ and ionized hydrocarbons with one to four carbon atoms per molecule $\left(C_{1}-C_{4}\right)$ were detected during devolatilization, as shown in Figure 3. However, the lengths of the carbon chains in the released hydrocarbons were probably initially longer before thermal decomposition and excitation in the QMS. The release of hydrocarbon chains in the low-temperature region was especially pronounced for TW but also evident for TFR. The release of $\mathrm{H}_{2}$ and $\mathrm{CO}$ was not pronounced in the low-temperature region. Off-gas analysis of HTT, PA, PB, and CC showed less intensity of ionized hydrocarbons like $\mathrm{CH}_{4}{ }^{+}, \mathrm{C}_{2} \mathrm{H}_{5}{ }^{+}, \mathrm{C}_{4} \mathrm{H}_{9}{ }^{+}$(see Figure 3d-g). $\mathrm{H}_{2}$ and $\mathrm{CO}$ were detected at $500-800^{\circ} \mathrm{C}$ for high-temperature pre-treated bio-coals. According to Yang [35,38], this is likely caused by cracking of residual lignin, which contains aromatic rings.

It has earlier been found that the reduction rate of iron oxide was higher when charcoal containing $18 \%$ volatiles was used in agglomerates compared to when only coke was used [39]. It has also been reported that $\mathrm{H}_{2}$ gas released up to $500{ }^{\circ} \mathrm{C}$ can at least partly be utilized in the reduction of iron ore $[40,41] . \mathrm{H}_{2}$ gas released at higher temperatures is known to improve the reduction efficiency and thus can reduce carbon consumption [42]. 
- Mass, $(\%)---\mathrm{H}_{2}-\mathrm{H}_{2} \mathrm{O}-\mathrm{CO}-\mathrm{CO}_{2}-\mathrm{CH}_{4}{ }^{+}-\mathrm{C}_{2} \mathrm{H}_{5}{ }^{+}-\mathrm{C}_{4} \mathrm{H}_{9}{ }^{+}$

(a)
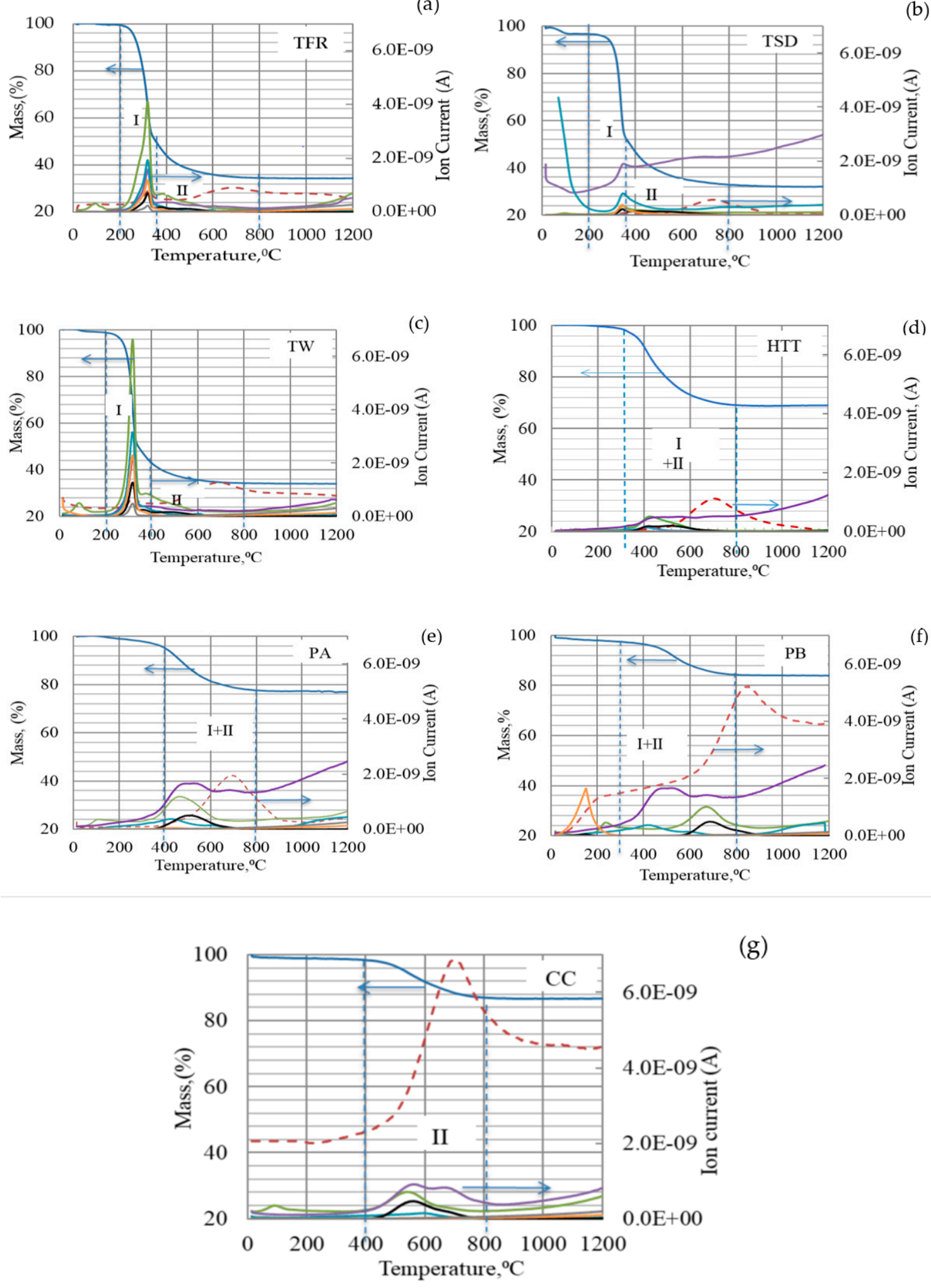

$(\mathrm{g})$

Figure 3. TGA-QMS analysis of different types of bio-coals: (a) TFR; (b) TSD; (c) TW; (d) HTT; (e) PA; (f) $\mathrm{PB}$; (g) $\mathrm{CC}$ in Argon at a heating rate of $5^{\circ} \mathrm{C} / \mathrm{min}$ up to $120{ }^{\circ} \mathrm{C}$. 


\section{Kinetic Analysis}

The mass loss at three heating rates $\left(5,10\right.$, and $\left.15^{\circ} \mathrm{C} / \mathrm{min}\right)$ was recorded for each of the bio-coal materials; data recorded for TFR are shown in Figure 4. The extent of conversion degree, $\alpha$, was calculated according to Equation (4) for all bio-coals tested.

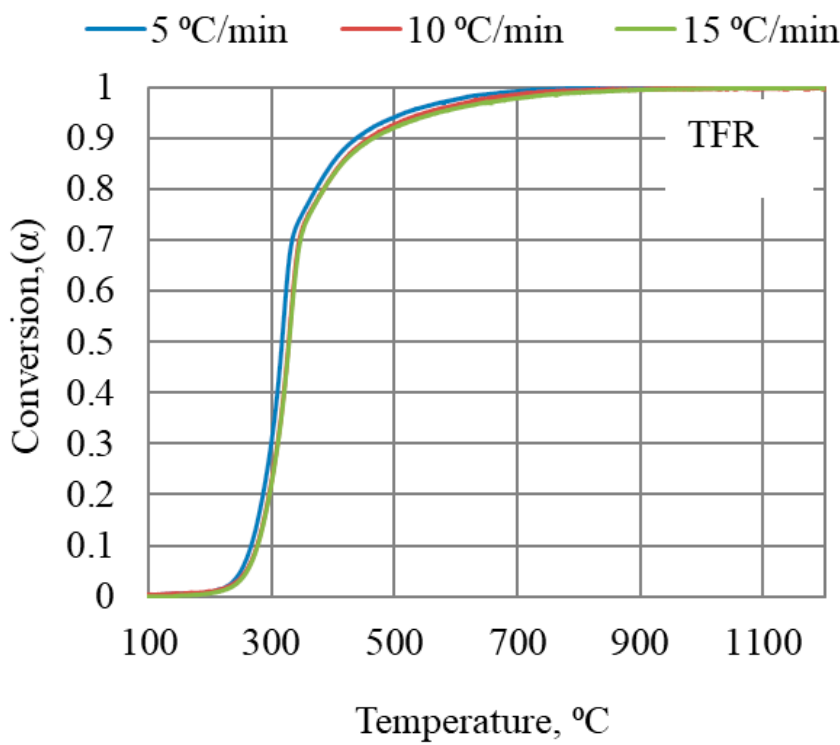

Figure 4. Conversion degrees for torrefied forest residue as a function of temperature in TGA at three heating rates up to $1200^{\circ} \mathrm{C}$.

The results obtained from TGA were elaborated according to the iso-conversional KAS model to calculate the kinetic parameters according to Equation (8) for a given value of conversion, $\alpha$, in the range from 0.1 to 0.99 for all different heating rates. The KAS plot of $\ln \frac{\beta_{I}}{T_{\alpha I}^{2}}$ versus $\frac{1000}{T_{\alpha I}} \mathrm{~K}^{-1}$ for different values of conversion is shown in Figure 5. The apparent activation energies were obtained from the slope, and the correlation coefficients, $\mathrm{R}^{2}$, are given in Table 4 . The correlation coefficients corresponding to linear fittings were in the range from 0.996 to 1.000 .

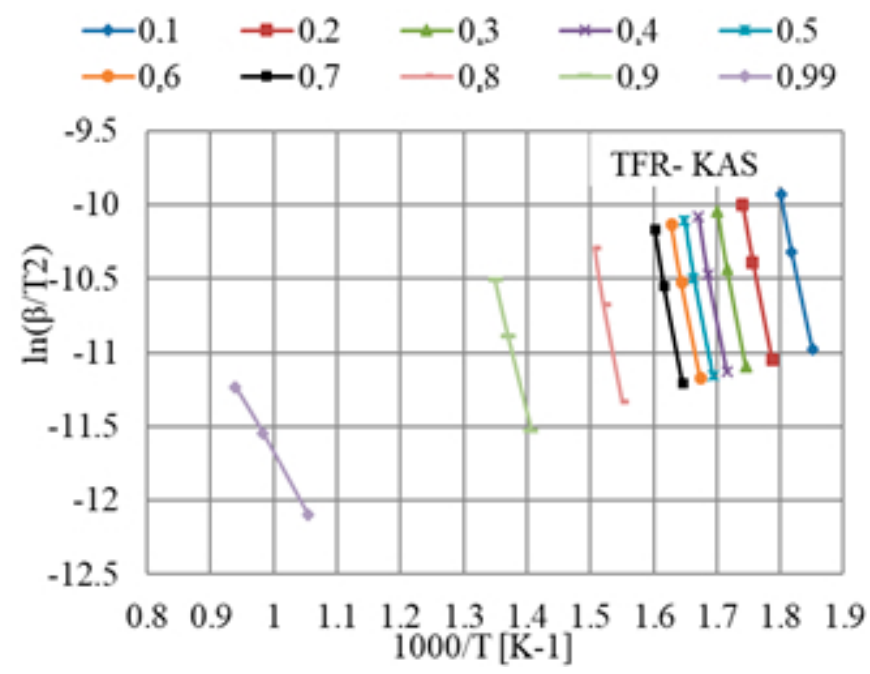

Figure 5. Plot deduced by applying the KAS model for the calculation of the activation energy for TFR at different heating rates. 
Table 4. Kinetic parameters obtained from the KAS model for different bio-coals, $\mathrm{E}_{\mathrm{a}}$, activiation energy in $\mathrm{kJ} / \mathrm{mol}$. $\mathrm{R}^{2}$, correlation coefficients.

\begin{tabular}{|c|c|c|c|c|c|c|c|c|c|c|c|c|c|c|}
\hline \multirow{2}{*}{ Conversion, $\alpha$} & \multicolumn{2}{|c|}{ TFR } & \multicolumn{2}{|c|}{ TSD } & \multicolumn{2}{|c|}{ TW } & \multicolumn{2}{|c|}{ HTT } & \multicolumn{2}{|c|}{ PA } & \multicolumn{2}{|c|}{ PB } & \multicolumn{2}{|c|}{$\mathrm{CC}$} \\
\hline & $E_{a}$ & $\mathbf{R}^{2}$ & $\mathrm{E}_{\mathbf{a}}$ & $\mathbf{R}^{2}$ & $E_{a}$ & $\mathbf{R}^{2}$ & $\mathbf{E}_{\mathbf{a}}$ & $\mathbf{R}^{2}$ & $E_{a}$ & $\mathbf{R}^{2}$ & $E_{a}$ & $\mathbf{R}^{2}$ & $\mathrm{E}_{\mathbf{a}}$ & $\mathbf{R}^{2}$ \\
\hline 0.1 & 169 & 0.999 & 149 & 0.998 & 111 & 1.000 & 361 & 0.981 & 145 & 1.000 & 449 & 0.996 & 297 & 0.999 \\
\hline 0.2 & 179 & 1.000 & 158 & 0.997 & 120 & 0.999 & 278 & 1.000 & 189 & 1.000 & 411 & 0.996 & 271 & 1.000 \\
\hline 0.3 & 185 & 0.998 & 162 & 0.997 & 123 & 0.999 & 246 & 0.999 & 222 & 0.997 & 272 & 1.000 & 271 & 1.000 \\
\hline 0.4 & 191 & 0.997 & 158 & 0.999 & 124 & 1.00 & 238 & 0.997 & 232 & 1.000 & 225 & 0.999 & 249 & 1.000 \\
\hline 0.5 & 185 & 0.998 & 159 & 0.997 & 124 & 0.999 & 274 & 1.000 & 269 & 1.000 & 215 & 1.000 & 260 & 0.997 \\
\hline 0.6 & 186 & 0.999 & 191 & 1.000 & 123 & 0.999 & 263 & 1.000 & 235 & 0.999 & 204 & 1.000 & 215 & 0.998 \\
\hline 0.7 & 192 & 0.998 & 269 & 1.000 & 124 & 0.999 & 161 & 1.000 & 250 & 0.999 & 202 & 0.999 & 195 & 0.998 \\
\hline 0.8 & 194 & 0.997 & 385 & 0.999 & 124 & 0.999 & 135 & 1.000 & 243 & 1.000 & 158 & 1.000 & 194 & 0.997 \\
\hline 0.9 & 143 & 1.000 & 252 & 1.000 & 90 & 0.999 & 99 & 0.999 & 221 & 0.997 & 139 & 1.000 & 139 & 0.999 \\
\hline 0,99 & 61 & 0.999 & 285 & 0.997 & 78 & 0.999 & 58 & 1.000 & 122 & 0.996 & 77 & 1.000 & 38 & 1.000 \\
\hline Average value & 169 & - & 217 & - & 114 & - & 211 & - & 213 & - & 235 & - & 213 & - \\
\hline
\end{tabular}

As can be seen in Table 4, the highly volatile bio-coals TFR and TW had quite stable values of $E_{a}$ up to the conversion degree of 0.8, while TSD showed an increasing trend in $\mathrm{E}_{\mathrm{a}}$ from 0.5, reaching a maximum at the conversion of 0.8 . Both TFR and TW had low $E_{a}$ at a high conversion degree. HTT, $\mathrm{PB}$, and $\mathrm{CC}$ showed a similar behavior, with a high $\mathrm{E}_{\mathrm{a}}$ value at a low conversion degree, decreasing with the increase of the conversion degree, whereas PA behaved differently. However, the general levels of $\mathrm{E}_{\mathrm{a}}$ at an intermediate conversion degree were quite similar for all four lowly volatile bio-coals. In general, these also had comparably high $\mathrm{E}_{\mathrm{a}}$ at the initial conversion degrees due to volatiles with weak bonds already being removed during torrefaction or pyrolysis. For highly volatile bio-coals, TW differed from TFR and TSD by having, in general, lower $\mathrm{E}_{\mathrm{a}}$ values. Variations in $\mathrm{E}_{\mathrm{a}}$ with the conversion degree for a bio-coal are likely due to different reactions occurring in parallel.

The KAS model assumes the same reaction occurring at a specific conversion degree. For complex materials like bio-coals, it is difficult to make detailed comparisons between materials, as different reactions may occur at the same conversion degree at different temperatures. Furthermore, there are overlapping reactions occurring at a given conversion degree and temperature. Differences in the conversion degree for different heating rates are in general not very large, as can be seen in Figure 4. Thus, measurement errors can have a significant influence on the calculated $E_{a}$ values. Further parameters influencing the reaction rate parameter are the origin of wood used in the actual processing of the bio-coal as well as the presence of catalyzing elements in the ash.

Among the tested materials, the content of catalyzing components such as $\mathrm{CaO}$ and $\mathrm{K}_{2} \mathrm{O}$ varied as did the content of acid components like $\mathrm{SiO}_{2}$. This was especially significant for $\mathrm{TW}$, which contains substantial amounts of $\mathrm{CaO}$ and $\mathrm{K}_{2} \mathrm{O}$ and very low amounts of $\mathrm{SiO}_{2}$. TSD has comparably low contents of oxides, including $\mathrm{CaO}$ and $\mathrm{K}_{2} \mathrm{O}$. This might be one reason for the lowest $\mathrm{E}_{\mathrm{a}}$ estimate for TW in comparison to other bio-coals with higher volatile content, which is in agreement with reference [18].

One important property when selecting a bio-coal for bio-agglomerates is the release of volatiles at temperatures at which they can be used for reduction. TW is likely not the best selection, because of the ease of volatilization at low temperature; with high contents of $\mathrm{K}_{2} \mathrm{O}$ and $\mathrm{P}_{2} \mathrm{O}_{5}$, the use of both TW and TFR will be restricted from a process and product quality point of view, respectively. Both TSD and CC are suitable for BF applications because of their low contents of $\mathrm{K}_{2} \mathrm{O}$ and $\mathrm{P}_{2} \mathrm{O}_{5}$. In addition, $\mathrm{CC}$ is devolatilized at a higher temperature, forming $\mathrm{H}_{2}$ and $\mathrm{CO}$ that will contribute to the reduction reactions. On the basis of their devolatilization behavior, bio-coals pretreated at high temperature are considered suitable for use in agglomerates, provided the ash chemistry is suitable for the BF. Although TSD is a highly volatile bio-coal, its higher $\mathrm{E}_{\mathrm{a}}$ indicates that the release of VM might be slightly delayed and may contribute to the reduction at higher temperature. An additional advantage of TSD is a comparably high yield when produced from raw biomass; in addition, TSD is available in sufficient amounts for upscaling studies.

The QMS analysis, summarized in Figure 6, indicated that $\mathrm{CH}_{4}$ formed at lower temperatures reacted with $\mathrm{CO}_{2}$, forming $\mathrm{CO}$ and $\mathrm{H}_{2}$, while hydrocarbons released at higher temperatures reacted 
with $\mathrm{H}_{2} \mathrm{O}$, forming $\mathrm{H}_{2}$ and some $\mathrm{CO}$. $\mathrm{CO}$ formed also at low temperatures may contribute to the reduction of hematite already in the shaft, whereas $\mathrm{H}_{2}$ formed at higher temperatures will contribute to the reduction of lower iron oxides.
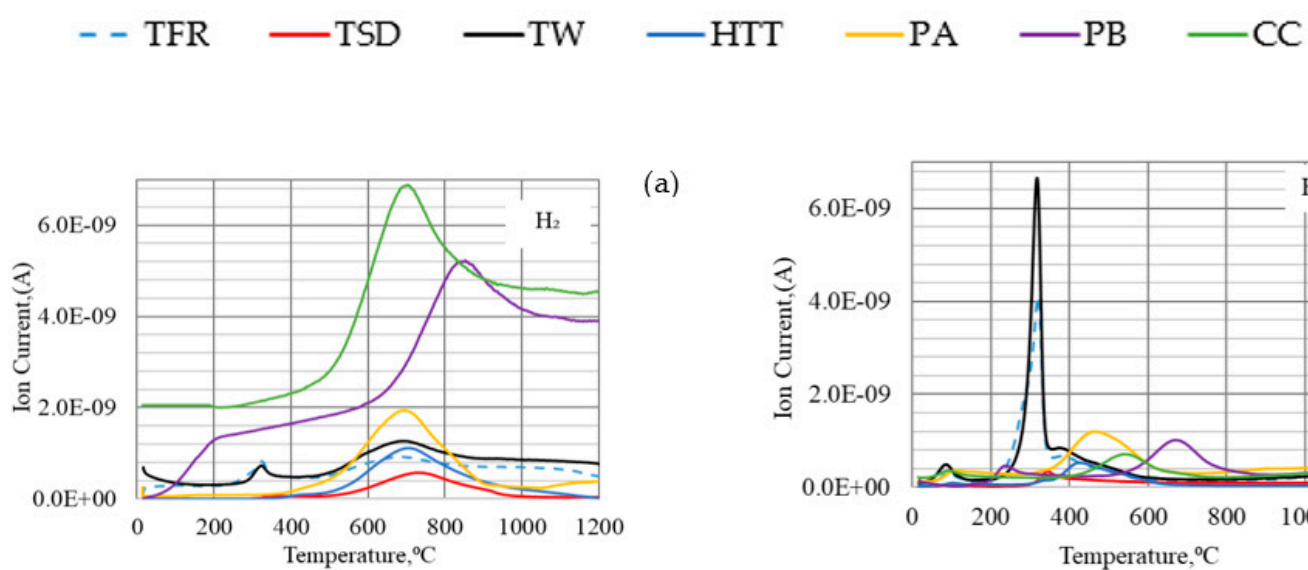

(a)

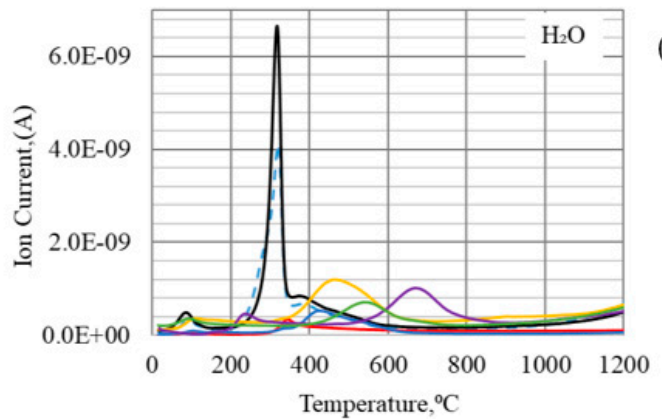

(b)
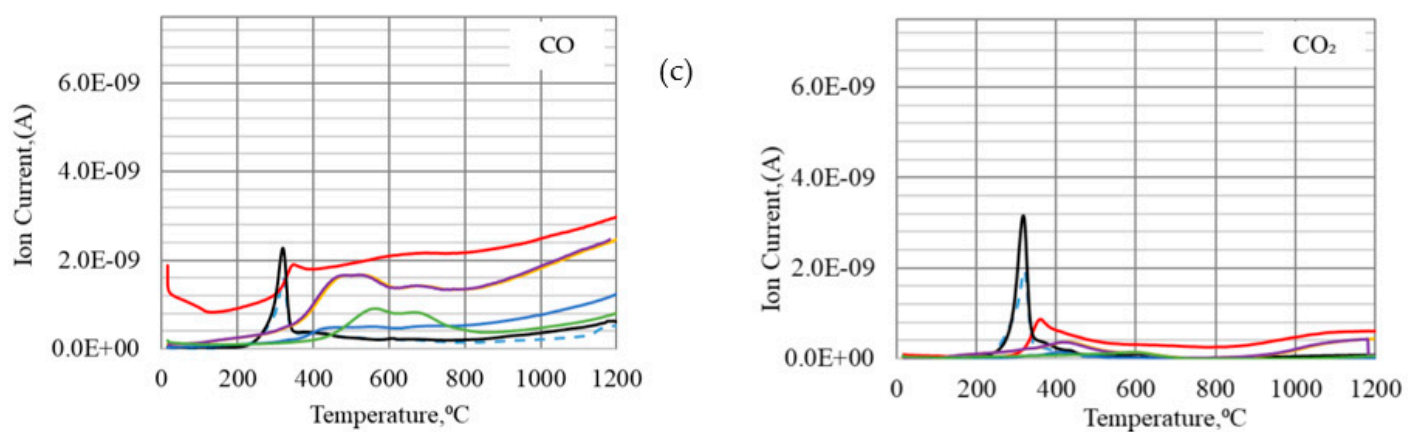

(d)

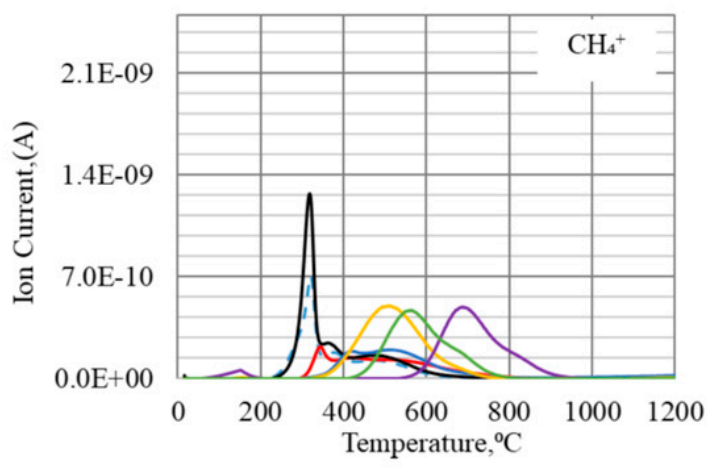

(e)

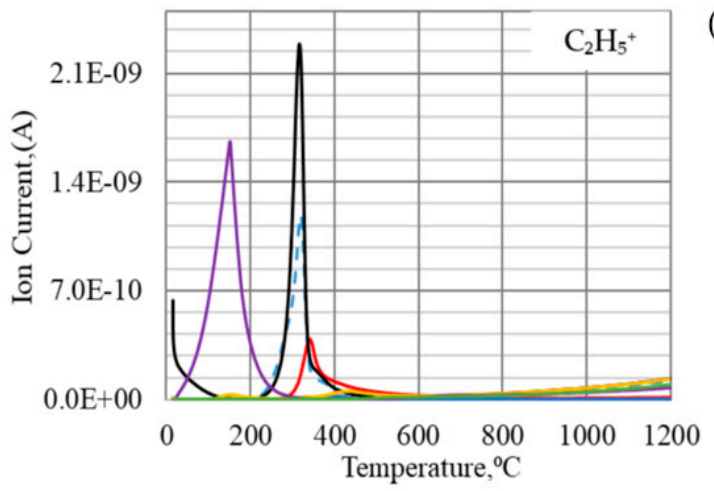

(f)

Figure 6. Off-gas analysis of (a) $\mathrm{H}_{2} ;$ (b) $\mathrm{H}_{2} \mathrm{O}$; (c) $\mathrm{CO}$; (d) $\mathrm{CO}_{2} ;$ (e) $\mathrm{CH}_{4}{ }^{+}$; (f) $\mathrm{C}_{2} \mathrm{H}_{5}{ }^{+}$for different types of bio-coals.

\section{Conclusions}

It was found that devolatilization is affected by the bio-coal properties that are linked to volatile contents and ash components.

Bio-coal with a low volatile content will release the volatiles at a comparatively high temperature, ensuring that the generated reducing gases can contribute to the reduction in the agglomerates with iron oxide. However, bio-coals with high $\mathrm{K}_{2} \mathrm{O}$ and $\mathrm{P}_{2} \mathrm{O}_{5}$ should be avoided because of their effect on process and product quality. 
Bio-coals with a high volatile content and, at the same time, a high content of the ash component catalyzing the devolatilization, should be avoided, as the volatile will be released at low temperature when the contribution to the reduction is limited.

Bio-coasl with a high volatile content and a low content of catalyzing components will release their volatiles later, and it is possible that this will occur at the temperature at which the formed CO can reduce higher iron oxides. When used in the $\mathrm{BF}$, this material has the advantage of high yield from raw biomass.

High volatile content and high content of $\mathrm{K}_{2} \mathrm{O}$ and $\mathrm{CaO}$ in bio-coal result in low $\mathrm{E}_{\mathrm{a}}$ for devolatilization. Bio-coals with low content of volatiles have in general high $\mathrm{E}_{\mathrm{a}}$ for devolatilization, as volatiles with weak bonds are already released during torrefaction or pyrolysis.

Among the tested materials, TSD appears to be the most suitable material to be utilized in bio-agglomerates in the $\mathrm{BF}$, in addition to $\mathrm{CC}$. Both of these materials have low contents of the catalyzing ash components and $\mathrm{P}_{2} \mathrm{O}_{5}$.

Author Contributions: A.A.E.-T. conceived and design the experiments, performed the experiments, analyzed the data, wrote the first draft of paper, reviewed and wrote the paper; L.S.O., supervision, reviewed and wrote the paper; B.B., supervision, reviewed and wrote the paper; H.M.A., supervision.

Funding: The research was funded by Bio-agglomerate project, grant number 156334.

Acknowledgments: Financial support from the Swedish Energy Agency (Energimyndigheten) for research within the bio-agglomerate project is gratefully acknowledged. For additional support, the following companies and institutions are acknowledged: BioEndev, Swerim AB, SSAB Merox, LKAB and SSAB special steel. The research has been partly financed by CAMM, Center of Advanced Mining and Metallurgy at LTU.

Conflicts of Interest: The authors declare no conflict of interest.

\section{References}

1. Geerdes, M.; Chaigneau, R.; Kurunov, I. Modern Blast Furnace Ironmaking: An Introduction, 3rd ed.; IOS Press: Amsterdam, The Netherlands, 2015; pp. 1-215.

2. Xu, C.; Cang, D. A Brief Overview of Low $\mathrm{CO}_{2}$ Emission Technologies for Iron and Steel Making. J. Iron Steel Res. Int. 2010, 17, 1-7. [CrossRef]

3. Hannu, S.; Timo, F. Towards More Sustainable Ironmaking-An Analysis of Energy Wood Availability in Finland and the Economics of Charcoal Production. Sustainability 2013, 5, 1188-1207.

4. Steel's Contribution to a Low Carbon Future and Climate Resilient Societies. Available online: https:/ / www.worldsteel.org/publications/bookshop/product-details \{\}Steel-s-Contribution-to-a-LowCarbon-Future--2018-update- \{\}PRODUCT \{\}Steel-s-Contribution-to-a-Low-Carbon-Future \{\} .html (accessed on 14 April 2018).

5. Wang, C.; Mellin, P.; Lövgren, J.; Nilsson, L.; Yang, W.; Salman, H.; Hultgren, A.; Larsson, M. Biomass as blast furnace injectant-Considering availability, pretreatment and deployment in the Swedish steel industry. Energy Convers. Manag. 2015, 102, 217-226. [CrossRef]

6. Feliciano-Bruzual, C. Charcoal injection in blast furnaces (Bio-PCI): $\mathrm{CO}_{2}$ reduction potential and economic prospects. J. Mater. Res. Technol. 2014, 3, 233-243. [CrossRef]

7. Alexander, B.; Dieter, S.; Miguel, F. Charcoal Behaviour by Its Injection into the Modern Blast Furnace. ISIJ Int. 2010, 50, 81-88.

8. Skogsdata 2018. Available online: https://www.slu.se/en/Collaborative-Centres-and-Projects/theswedish-national-forest-inventory/forest-statistics/skogsdata/ (accessed on 12 December 2018).

9. Fick, G.; Mirgaux, O.; Neau, P.; Patisson, F. Using biomass for pig iron production: A technical, environmental and economical assessment. Waste Biomass Valoris 2014, 5, 43-55. [CrossRef]

10. Chen, W.; Du, S.; Tsai, C.; Wang, Z. Torrefied biomasses in a drop tube furnace to evaluate their utility in blast furnaces. Bioresour. Technol. 2012, 111, 433-438. [CrossRef] [PubMed]

11. Bridgwater, A. The production of biofuels and renewable chemicals by fast pyrolysis of biomass. Int. J. Glob. Energy Issues 2007, 27, 160-203. [CrossRef]

12. Van der Stelt, M.J.C.; Gerhauser, H.; Kiel, J.H.A.; Ptasinski, K.J. Biomass upgrading by torrefaction for the production of biofuels: A review. Biomass Bioenergy 2011, 35, 3748-3762. [CrossRef] 
13. Keown, D.M.; Favas, G.; Hayashi, J.I.; Li, C.Z. Volatilisation of alkali and alkaline earth metallic species during the pyrolysis of biomass: Differences between sugar cane bagasse and cane trash. Bioresour. Technol. 2005, 96, 1570-1577. [CrossRef]

14. Agblevor, F.A.; Besler, S. Inorganic compounds in biomass feedstocks. 1. Effect on the quality of fast pyrolysis oils. Energy Fuels 1996, 10, 293-298. [CrossRef]

15. Jensen, P.A.; Frandsen, F.J.; Dam-Johansen, K.; Sander, B. Experimental Investigation of the Transformation and Release to Gas Phase of Potassium and Chlorine during Straw Pyrolysis. Energy Fuels 2000, 14, 1280-1285. [CrossRef]

16. Nowakowski, D.J.; Jones, J.M.; Brydson, R.M.D.; Ross, A.B. Potassium catalysis in the pyrolysis behaviour of short rotation willow coppice. Fuel 2007, 86, 2389-2402. [CrossRef]

17. Raveendran, K.; Ganesh, A.; Khilar, K.C. Influence of mineral matter on biomass pyrolysis characteristics. Fuel 1995, 74, 1812-1822. [CrossRef]

18. Fahmi, R.; Bridgwater, A.V.; Darvell, L.I.; Jones, J.M.; Yates, N.; Thain, S.; Donnison, I.S. The effect of alkali metals on combustion and pyrolysis of Lolium and Festuca grasses, switchgrass and willow. Fuel 2007, 86, 1560-1569. [CrossRef]

19. Vyazovkin, S.; Wight, C.A. Kinetics in solids. Annu. Rev. Phys. Chem. 1997, 48, 125-149. [CrossRef] [PubMed]

20. Galwey, A.K.; Brown, M.E. Kinetic Background to Thermal Analysis and Calorimetry. Princ. Pract. 1998, 1, 147-223.

21. Cai, J.M.; Bi, L.S. Kinetic analysis of wheat straw pyrolysis using isoconversional methods. J. Therm. Anal. Calorim. 2009, 98, 325-330. [CrossRef]

22. Slopiecka, K.; Bartocci, P.; Fantozzi, F. Thermogravimetric analysis and kinetic study of poplar wood pyrolysis. Appl. Energy 2012, 97, 491-497. [CrossRef]

23. Brachi, P.; Miccio, F.; Miccio, M.; Ruoppolo, G. Isoconversional kinetic analysis of olive pomace decomposition under torrefaction operating conditions. Fuel Process. Technol. 2015, 130, 147-154. [CrossRef]

24. Aboyade, A.O.; Hugo, T.J.; Carrier, M.; Meyer, E.L.; Stahl, R.; Knoetze, J.H.; Görgens, J.F. Non-isothermal kinetic analysis of the devolatilization of corn cobs and sugar cane bagasse in an inert atmosphere. Thermochim. Acta 2011, 517, 81-89. [CrossRef]

25. Kongkaew, N.; Pruksakit, W.; Patumsawad, S. Thermogravimetric Kinetic Analysis of the Pyrolysis of Rice Straw. Energy Procedia 2015, 79, 663-670. [CrossRef]

26. Mani, T.; Murugan, P.; Abedi, J.; Mahinpey, N. Pyrolysis of wheat straw in a thermogravimetric analyzer: Effect of particle size and heating rate on devolatilization and estimation of global kinetics. Chem. Eng. Res. Des. 2010, 88, 952-958. [CrossRef]

27. Biagini, E.; Fantei, A.; Tognotti, L. Effect of the heating rate on the devolatilization of biomass residues. Thermochim. Acta 2008, 472, 55-63. [CrossRef]

28. Doddapaneni, T.R.K.C.; Konttinen, J.; Hukka, T.I.; Moilanen, A. Influence of torrefaction pretreatment on the pyrolysis of Eucalyptus clone: A study on kinetics, reaction mechanism and heat flow. Ind. Crop. Prod. 2016, 92, 244-254. [CrossRef]

29. Tran, K.Q.; Bach, Q.V.; Trinh, T.T.; Seisenbaeva, G. Non-isothermal pyrolysis of torrefied stump-A comparative kinetic evaluation. Appl. Energy 2014, 136, 759-766. [CrossRef]

30. Vyazovkin, S.; Wight, C.A. Isothermal and non-isothermal kinetics of thermally stimulated reactions of solids. Int. Rev. Phys. Chem. 1998, 17, 407-433. [CrossRef]

31. Sbirrazzuoli, N. Determination of pre-exponential factors and of the mathematical functions $f(a)$ or $G$ (a) that describe the reaction mechanism in a model-free way. Thermochim. Acta 2013, 564, 59-69. [CrossRef]

32. Vyazovkin, S.; Burnham, A.K.; Criado, J.M.; Pérez-Maqueda, L.A.; Popescu, C.; Sbirrazzuoli, N. ICTAC Kinetics Committee recommendations for performing kinetic computations on thermal analysis data. Thermochim. Acta 2011, 520, 1-19. [CrossRef]

33. Starink, M.J. The determination of activation energy from linear heating rate experiments: A comparison of the accuracy of isoconversion methods. Thermochim. Acta 2003, 404, 163-176. [CrossRef]

34. Ahmed, H.M.; Persson, A.; Okvist, L.S.; Bjorkman, B. Reduction Behaviour of Self-reducing Blends of In-plant Fines in Inert Atmosphere. ISIJ Int. 2015, 55, 2082-2089. [CrossRef]

35. Yang, H.; Yan, R.; Chen, H.; Lee, D.H.; Zheng, C. Characteristics of hemicellulose, cellulose and lignin pyrolysis. Fuel 2007, 86, 1781-1788. [CrossRef] 
36. Carrier, M.; Auret, L.; Bridgwater, A.; Knoetze, J.H. Using Apparent Activation Energy as a Reactivity Criterion for Biomass Pyrolysis. Energy Fuels 2016, 30, 7834-7841. [CrossRef]

37. Ren, S.; Lei, H.; Wang, L.; Bu, Q.; Chen, S.; Wu, J. Thermal behaviour and kinetic study for woody biomass torrefaction and torrefied biomass pyrolysis by TGA. Biosyst. Eng. 2013, 116, 420-426. [CrossRef]

38. Yang, H.; Yan, R.; Chen, H.; Lee, D.H.; Liang, D.T.; Zheng, C. Mechanism of Palm Oil Waste Pyrolysis in a Packed Bed. Energy Fuels 2006, 20, 1321-1328. [CrossRef]

39. Konishi, H.; Ichikawa, K.; Usui, T. Effect of residual volatile matter on reduction of iron oxide in semi-charcoal composite pellets. ISIJ Int. 2010, 50, 386-389. [CrossRef]

40. Lin, H.Y.; Chen, Y.W.; Li, C. The mechanism of reduction of iron oxide by hydrogen. Thermochim. Acta 2003, 400, 61-67. [CrossRef]

41. Pineau, A.; Kanari, N.; Gaballah, I. Kinetics of reduction of iron oxides by H2: Part I: Low temperature reduction of hematite. Thermochim. Acta 2006, 447, 89-100. [CrossRef]

42. Biswas, A.K. Principles of Blast Furnace Ironmaking; Cootha Publishing House: Brisbane, Australia, 1981; pp. 1-512.

(C) 2019 by the authors. Licensee MDPI, Basel, Switzerland. This article is an open access article distributed under the terms and conditions of the Creative Commons Attribution (CC BY) license (http://creativecommons.org/licenses/by/4.0/). 